\title{
Market Access and Proportionality: Lessons from Gourmet
}

\author{
Xiaobing Li \\ Beijing UpRight Law Firm \\ Suit 1007, Kuntai International Mansion \\ Yi NO.12 Chaowai Street, Chaoyang District, Beijing 100020, China \\ Tel: 86-10-5879-7955 E-mail: 1xbto@vip.sina.com \\ Lijun Jiang \\ School of Law, Renmin University of China \\ 59 Zhongguan Cun Street, Beijing 100872, China \\ E-mail: lisalijun@gmail.com \\ Accepted: June 17, $2011 \quad$ Published: December 1, 2011 \\ URL: http://dx.doi.org/10.5539/ass.v7n12p56
}

Received: April 29, 2011

doi:10.5539/ass.v7n12p56

\begin{abstract}
The touchstone of the judgement of the Court of Justice in Gourmet has to be seen as a revolution of Article 28 . It provides particularly significant new insights into the criteria of this Article. In this judgement, the court of Justice has begun to use a more realistic and flexible approach instead of formalistic method. It is a revolution that replaces the selling arrangement with market access. Furthermore, the principle of proportionality in Gourmet opens a new door for the public interests that can not be ignored by the Court of Justice.

In this paper, we focus on the common market and the proportionality principle that are the most important lessons we can learn from Gourmet. In order to understand these two aspects clearly and fully, we will firstly discuss the essentials of Gourmet: in other words, the detailed facts of the case. These include the judgement of the Court of Justice and the opinion of the Advocate Generals. In the process, we will see clearly how the Court of Justice develops the selling arrangement into the market access approach and how the Court of Justice use and analysis the proportionality principle in this case. These will provide a basic understanding of the Gourmet case.

Finally, the discussions of the proportionality principle will help to deepen our concept of the common market. In this part, it is necessary to understand the concept and the importance of the proportionality principle. Consequently, we will investigate some of its legal and historical roots. In the following section, we will show how the principle is to be used. We will list the two common standards of the proportionality principle: suitability and necessary. The most important discussion will concern the different roles of the Court of Justice and national courts. This will entail the essential question of the proportionality principle: what is the proper relationship between the Court of Justice and national courts when applying the proportionality principle?
\end{abstract}

Keywords: Market access, Gourmet case, Proportionality principle

\section{Background and Introduction}

'The internal market shall comprise an area without internal frontiers in which the free movement of goods, persons, services and capital is ensured in accordance with the provisions of this Treaty. '(Note 1)

We all know that the original and final aim of the European Union was to establish the perfect common market without any obstacle to free trade. In order to achieve this aim, many provisions and legislations of the EU have been established. Article 28 is a key provision of the EU and an extremely important driving force behind the free movement of goods. It states that: "Quantitative restrictions on imports and all measures having equivalent effect shall be prohibited between Member States." However, from a historical point of view, the Court of Justice took a different view to that set out in Article 28. In the Dassonville and Cassis de Dijon, the principle of Article 28 has been seen as the most sweeping text in the history. Almost any measure that potentially or indirectly hinders the import of goods may fall is prohibited by Article 28. Then comes the famous text Keck. 
This has been seen as a selling arrangement that is a more refined version of Article 28. However, the selling arrangement has been heavily debated because some regard it as too formalistic. History never stops.

The Gourmet, as a long awaited case, brings a new grounding and approach to Article 28. Indeed, it perfects its scope. The Court of Justice has accepted access to the common market as an ideal standard. It has states that 'if national provisions restricting or prohibiting certain selling arrangements are to avoid being caught by Article 30 (Article 28) of the Treaty, they must not be such a kind as to prevent access to the market by products from another Member State or to impede access any more than they impede the access of domestic products.' (Note 2) In the context of this approach, closer attention should be paid to the nature of the common market. The time is past for a formalist reading of the catalogue of restrictions. The Gourmet summarizes and develops the criteria of Article 28. The concept of market access to the common market is indeed a good lesson we can learn from the case Gourmet.

More importantly, in Gourmet, the Court of Justice began to shift the view of the simple integration of the common market. That means the Court of Justice has not oversimplified the concept of the common market. In order to achieve a higher level of common market, the Court of Justice has underlined the proportionality in Gourmet. What is the higher level of requirement? What all the Member States need is a common market that offers a high level protection to their public and national interests. In the past years, we can see clearly this as an achievement of the EU common market. However, it causes considerable concern to many Member States that the EU is sacrificing many basic elements, including public interests, consumer protection, and national policy for the integration of the EU market. There is every danger that there is a gap between the free movement of goods and public interests. We do not want to loss either of them. How can the Court of Justice step in to plug the gap? The principle of proportionality is the key to this problem. 'In order for public health concerns to be capable of justifying an obstacle to trade such as that inherent in the prohibition on advertising at issue in the main proceedings, the measure concerned must also be proportionate to the objective to be achieved and must not constitute either a means of arbitrary discrimination or a disguised restriction on trade between Member States.' (Note 3). It must keep a suitable balance between two competing interests: the common market and public interests. So the Gourmet opens a new door for the national and public interests. It shows a sign that the Court of Justice has begun to realize that the common market is not the only requirement and concern for the EU. The Court of Justice understands that it must protect the common market on the grounds of providing substantial protection for public interests.

\section{The essentials of Gourmet}

The judgement of the Court of Justice in Gourmet has been seen as a revolution of Article 28. It certainly provides particularly significant and new insights into the criteria of Article 28. In this judgement, the Court of Justice has begun to use a more realistic and flexible approach, instead of formalistic method. Furthermore, the principle of proportionality opens a new door for the public interests that cannot be ignored by the Court of Justice. So in the following parts, we will analyse two aspects of the Gourmet case. First of all, how does the Court of Justice transform a selling arrangement into a market access test? Furthermore, how does the Court of Justice decide to use the principle of proportionality?

\subsection{The fact of the case}

In Gourmet, according to Article 2 of the Alkoholreklamlagen (the Swedish Alcohol Advertising Law), 'in view of the health risks involved in alcohol consumption, alcoholic beverages should be marketed with particular moderation. In particular, advertisement or other marketing measures must not be insistent, involve unsolicited approaches or encourage alcohol consumption...'(Note 4) So, Swedish legislation provides a total ban on advertising on radio, television or in periodicals and other publications, except the specialist press. (Note 5)

However, GIP (Gourmet International Products AB) placed three pages of alcohol advertising in the periodical Gourmet, one page for red wine and two for whiskies. This magazine is printed in two editions, the first for the general public, and the second for subscribers only. 'Total circulation is around 25000 copies, of which some 9300 are accounted for by the subscriber edition. Of those $9,300,55$ percent are delivered to businesses in the drinks trade, 35 percent to other businesses and 10 percent to private individuals.' (Note 6) Therefore, this advertising directed at individuals breaches Article 2 of the Alcohol Advertising Law. The Swedish Consumer Ombudsman applied to Stockholm District Court for an injunction restraining GIP from placing such advertisements and imposing a fine in the event of non-compliance. However, GIP insists on the point that no injunction should be made because Article 2 of Swedish legislation is contrary to the Article 28 of Community law. Crucially, Article 2 imposes a measure the effect of which is equivalent to a quantitative restriction on imports of goods from other Member States. 
So there are two questions that the Stockholm District Court referred to the Court of Justice: is the national law imposing a total ban on certain advertising to be interpreted as a measure having equivalent effect to a quantitative restriction? If so, is this ban justified and proportionate for the protection of human life and health? On the one hand, the objective of the Alkoholreklamlagen is to restrict the marketing of alcoholic beverages to consumers. It lays down a mandatory requirement for the benefit of public health. On the other hand, the question is whether this restriction might be ensured by measures with less effect on trade? If so, the total ban on advertising is not proportionate, even though it concerns public health.

\subsection{Form selling arrangement to market access}

Is the Swedish law contrary to the Article 28 of community law? Does the community law really preclude a prohibition on advertisements? Either way, the case provides a good opportunity for the Court of Justice to rethink the nature of Article 28. In fact, the Court of Justice has already held that advertising restrictions can fall within the category of rules on selling arrangements referred to in Keck. In Keck, the Court of Justice created a distinction between the rules that relate directly to goods themselves and the rules that are called a selling arrangement. Certain selling arrangements were held to be outside of Article 28 because they are apply to goods from other Member States, where they are lawfully manufactured and marketed. Yet, the rules that lay down requirements to be met by such goods (such as those relating to designation, form, size, weight, composition, presentation, labelling, packaging) constitute measures equivalent to those prohibited by Article 30(Note 7). So, in post-Keck cases, advertising restrictions are seen as a selling arrangement and are therefore held to be outside the scope of the Article 28 of the Community Law. However, this kind of formalist dichotomy causes us ignore the discrimination in fact and focus on the catalogue of the prohibition. A formalistic reading of selling arrangements therefore strays far from the nature of the Article 28 of Community law.

In Gourmet, the Court of Justice states that if national provisions restricting or prohibiting certain selling arrangements are to avoid being caught by Article 30 of the Treaty, they must not be such a kind as to prevent access to the market by products from another Member State or to impede access any more than they impede the access of domestic products.' (Note 8) That means the Court of Justice takes a view of the facts of the case and thinks about the element of market access. The nature of Article 28 should be non-discriminatory both in law and fact. Consequently, certain selling arrangements, as stated by the Court of Justice, should apply to all relevant traders in the same manner in law and in fact, without the distinction between the national territories other member states. In Gourmet, there is no discrimination in law: there is no difference in provision between domestic and imported products in Swedish law. But does this situation reflect the potential discrimination in fact? It is not difficult to see that such a ban has a greater effect on imported goods than on those produced in the Member State concerned. 'Even without its being necessary to carry out a precise analysis of facts characteristic of the Swedish situation, which it is for the national court to do, the Court is able to conclude that, in the case of products like alcoholic beverages, the consumption of which id linked to traditional social practices and to local habits and customs, a prohibition of all advertising directed at consumers in the form of advertisements in the press, on the radio and on the television, the direct mailing of unsolicited material or the placing of posters in the public highway is liable to impede access to the market by products from other Member States more than it impedes access by domestic products, with which consumers are instantly more familiar.' (Note 9)

It is obvious that buying national brands of alcohol is a common consumer habit. Consumers do not like to change the brands they purchase. So, under this situation, the domestic products enjoy their monopoly even without advertising. Yet, imported products markets are at a disadvantage because a very small number of consumers will be interested in the new product without advertising. In fact, in the context of local habits, the role of advertising is to provide a message that creates a new market. Factual or potential inequality directly affects the new market. It is a strategy of development for the importers. Their aim is not to encourage more alcoholic beverage consumption but to persuade consumers to switch to their brand. This prohibition on advertising not only factually limits the form of marketing for an imported product but also prohibits the messages to domestic consumers. Access to the common market is actually blocked. Just as the opinion of $\mathrm{Mr}$ Advocate of General Jacobs states, "the advertising restrictions in issue not only are capable of hindering intra-Community trade but also in fact affect the marketing of domestic products differently from those from other Member States and impede the access of domestic products. That being so, the Keck and Mithouard exception could not in any event apply.' (Note 10) The Court of Justice agrees with the opinion of Mr Advocate of General Jacobs and states that 'a prohibition on advertising such as that at issue in the main proceedings must therefore be regarded as affecting the marketing of products from other Member States more heavily than the marketing of domestic products and as therefore constituting an obstacle to trade between Member States caught by Article 30 (Article 28) of the Treaty.' (Note 11) 
At this point, the Court of Justice diverged from a mechanical application of selling arrangements to a factual market access approach. It is a pivotal clarification of the Article 28. Although we can not deny the usefulness of the dichotomy between selling arrangements and product-related rules, pure and simple application of selling arrangements seems unworkable and ineffective. Selling arrangements pay more attention to the rules than the actual facts. However, the market access test is based on the facts of the cases. It provides flexible assessments case by case. The national law is examined in every detail. This is the only way to abolish unjustified obstacles

\subsection{The principle of proportionality}

Obviously, the Court of Justice answers the question concerning whether the Swedish advertising restriction constitutes an obstacle to trade between Member States as laid out in Article 28 of the Treaty. However, when may such an obstacle be justified by the protection of health and life of humans, which is a public interest ground recognised by Article 30 (ex Article 36) of the Treaty? It provides that: 'the provisions of Articles 28 and 29 shall not preclude prohibitions or restrictions on imports, exports or goods in transit justified on grounds of public morality, public policy or public security; the protection of health and life of humans, animals or plants; the protection of national treasures possessing artistic, historic or archaeological value; or the protection of industrial and commercial property. Such prohibitions or restrictions shall not, however, constitute a means of arbitrary discrimination or a disguised restriction on trade between Member States.' (Note 12)

This question brings us back to the Cassis de Dijon case. When we consider whether the restriction or prohibition of measures has equivalent effect for Article 28, there is a special exception named the mandatory requirement. If the Member States take a view of the effectiveness of fiscal supervision, the protection of public health, the fairness of commercial transaction and the defence of the consumer without distinction to imported and domestic goods, the national laws are not liable to Community law. That means the protection of human health against the excessive alcohol consumption may be a reasonable ground to derogate from Article 28. It is also pointed out by the Court of Justice that rules restricting the advertising of alcoholic beverages in order to combat alcohol abuse could reflect public health concerns and, as such, are justifiable. So the Court of Justice should consider whether this prohibition meets the condition of the mandatory requirements. If so, is this protection justifiable and appropriate in light if the rules of the internal market?

First of all, the Swedish Government's case rests soundly on the basis of protecting human health: in the view of the health risks involved in alcohol consumption, alcohol beverages should be marketed with particular moderation... the objective of the Alkoholreklamlagen is to restrict the possibilities of marketing alcoholic beverages to consumers. (Note 13) Furthermore, 'As pointed out by the Swedish and Finnish Governments, advertising restrictions are included among the aims of the European Alcohol Action Plan drawn up by the World Health organisation's Regional Office for Europe in 1993 and further developed for the period 2000 to 2005, and of the European Charter on Alcohol drawn up by the European Conference on Health, Society and Alcohol held by the same organisation in Paris in December 1995.' (Note 14) Thirdly, we can not see any distinction between imported and domestic goods in the context of public health concerns. The objective of the Swedish law is to reduce and restrict alcohol consumption. 'There is no evidence before the Court to suggest that the public health grounds on which the Swedish authorities rely have been diverted from their purpose and used in such a way as a discriminate against goods originating in other Member States or to protect certain national products indirectly.' (Note 15) So there is no doubt that public health concern of the Swedish law perfectly meets the conditions of the mandatory requirements.

However, does this mean that the national ban is justifiable and proportionate? What should the Court of Justice consider? First, the principle of proportionality: 'In order for public health concerns to be capable of justifying an obstacle to trade such as that inherent in the prohibition on advertising at issue in the main proceedings, the measure concerned must also be proportionate to the objective to be achieved and must not constitute either a means of arbitrary discrimination or a disguised restriction on trade between Member States.' (Note 16) Why does the Court of Justice point out this principle? How do the two parties of this case state?

The Swedish Government claims that the ban on advertising is not over-restrictive because the Swedish law does not restrict all advertising of alcoholic beverages. If they wish, they may ask the producer or importer to send advertising material to particular in restaurants, place it on the Internet, or in an 'editorial context or by asking the producer or importer to sent advertising material. (Note 17) These measures ensure that messages can be communicated to the consumers. Furthermore, it would seem that Member States are at liberty to decide on the degree of protection that they wish to afford to public health. We can not find any common or harmonised legislation concerning the manner of advertising alcoholic beverages. Different member states can regulate 
different degrees of protection according to their national situations. So the Swedish law concerning alcohol policy is totally flexible and reasonable.

On the contrary, GIP claims that this prohibition is disproportionate and imperfectly effective. A more limited policy could be used to achieve the same aim. Furthermore, 'It must be borne in mind that the Swedish policy on alcoholism is already catered for by the existence of the monopoly on retail sales, by the prohibition on sales to persons under the age of 20 years and by information campaigns.' (Note 18) The Commission also states that the prohibition does not appear to be particularly effective. (Note 19) From this view, Mr Advocate General Jacobs pays more attention to analysis of the facts and the possibilities of proportionality. He considers whether a less extensive prohibition might achieve the aim of reducing alcohol consumption. For instance, it is reasonable to focus on the young people or children because that section of the population is likely to be influenced by advertising. In particular, the prohibition of certain media methods that appeal to children and young people might be justified: for instance, street hoardings, mass-circulation newspapers and peak time television. In fact, many member states place such kinds of ban instead of the total ban. For the adult consumption, there are some examples of justified limitation. For example, if the limitation is covered by the obligation of particular moderation and concerns the dangers of human life and health, it is perfectly justified, or, if there is concern about the alcoholic strength of a particular drink. So an absolute ban on all media may be not justified. In his conclusion, "the Swedish aim of reducing alcohol consumption could be achieved just as effectively by measures less restrictive than a ban imposed on all such advertising in all sections of the media, in particular in so far as it extends to periodicals devoted to food and drink.' (Note 20)

However, the Court of Justice keeps silent on the question of whether or not the Swedish legislation on the advertising prohibition is proportionate. We should notice that it is not an escape route for the Court of Justice. The Court of Justice keeps away from the formalist method and pays more attention to the real facts of the whole case. An assessment of proportionality needs an analysis of the circumstances of law and fact. In the complex context of the Gourmet case, only the national court knows direct and detailed knowledge of the whole facts. So the national court is in a better position than the Court of Justice to provide this kind of deeper insight. In other words, it is in the best position to appreciate the social and local circumstances. This view constitutes a considerable change. In many cases, for example Cassis and Keck, the Court of Justice judges clinically and dispassionately whether the national law is contrary to the Community law. But, in Gourmet, the Court of Justice asks the national court to answer this question according to the national circumstances.

All in all, there are no clear guidelines for the Court of Justice's consideration of whether the advertising prohibition is contrary to the Article 28 of the Community law. Article 28 itself dose not preclude a prohibition on the advertising of alcoholic beverages. We cannot conclude that because advertising prohibition is a kind of selling arrangement, so Article 2 of the Alkoholrellamagen is not contrary to the Article 28 of Community law. That means the Court of Justice has moved away from the formalist selling arrangement approach. The causality between the selling arrangement and Article 28 is too formalist and simple. We can not judge the nature and the effect of the prohibition just because it might fall into this category. Market access should be the important concern for the Court of Justice, although market access is not a simple issue itself. It seems a standard question for the Court of Justice and national courts to answer: does the national prohibition impede the market access to the EU common market?

Although the Court of Justice does not answer on the question of proportionality, this does not mean that the Court of Justice does not give the guidance for the national court. 'Article 30 and 36 of the Treaty do not preclude a prohibition on the advertising of alcoholic beverages such as that laid down in Article 2 of the Alkoholreklamlagen, unless it is apparent that, in the circumstances of law and of fact which characterise the situation in the Member State concerned, the protection of public health against the harmful effects of alcoholic can be ensured by measures having less effect on intra-Community trade.' (Note 21) So it is a standing point for the Court of Justice to keep the balance between the Community law and public interests. That brings a new question concerning how the Court of Justice adjusts to the relationship between the internal market and the protection of public interests? To some extent, public interests and the internal market are conflicting interests for the Court of Justice. On the one hand, reasonable legislation aims to protect human health and the public interest. On the other hand, the market in imports is related to the free movement of goods. How to resolve these conflicting interests between them? Here, we must know that although the final aim of the Community law is to ensure the free movement of goods and the establishment of common market, protection of the public interests is very significant as well. Ensuring EU market without internal frontiers and free movement of goods, persons, services, and capital are core concerns of Community law. Hence, Article 28. It is a key principle concerning the integration of the EC market that influences the whole of production and consumption activities in the 
Community. However, from the other view, the Court of Justice should not simply protect the common market. The common market might be more effective and just if established on the ground of a high level of protection of public interests.

\section{The Role of the Court of Justice and Proportionality}

\subsection{The essential problem of the current status}

In the previous chapter, we have mentioned that the concept of common market is the most important concern for the Court of Justice. That is because it is the original aim of the European Union. So all the economic activities within the scope of the EU should meet the condition of provision of access to the common market. Therefore, it is not surprising that the Court of Justice, as the powerful institution of European Union, tried to interpret Article 28 in this way. However, the role of the Court of Justice seems less easy than we suggested. In other words, market access is indeed the most important aim of the European Union, but it should be not the only concern of the Court of Justice. There are also many significant principles to be considered when applying the EC law. For example, the basic principles include proportionality, legal certainty and legitimate expectations, non-discrimination, transparency and so on. So theses are the higher level requirements that the Court of Justice should meet. This is the hidden danger of the Court of Justice. In past years, many Member States have been worried about the developing direction of the European Union. A large proportion of the efforts we can see concern the European common market. At the same time, should not we protect the national and public interests within the European Union? The Principle of proportionality must be really proportionate. This is the complex context of the case Gourmet. So, it is necessary to discuss the relationship between the role of the Court of Justice and the proportionality principle.

We all know that European law is based on the treaties that all the member states signed and applied in the same way. So how the European law is interpreted and applied is significant to the whole running of the European Union. The Court of Justice has the power and competence to settle all legal issues within the scope of the European Union. So the judicial role of the Court of Justice as a safeguard is to ensure the correct interpretation and application of European treaties and to supervise all the activities of the Community. However, this is not easy or simple work for the Court of Justice. Many different factors can influence the judicial decisions. It is therefore a big challenge for the Court of Justice to consider the degree of the scrutiny, especially in the context of the relationship between the interests of the Community and those of Member States. The Court of justice must consider not only the nature and objectives of the Community law but also the national interests and position of the national laws. So the decision-making process is far from clear-cut for the Court of Justice. As we have considered above, the principle of proportionality in Article 28 and its application in EC law is a big concern for the Court of Justice and all the Member States. In many historical cases, national rules indeed constitute a restriction on the free movement of goods within the Community, which is obviously contrary to Article 28 of the EU law. Although the Member State usually states one of the reasonable grounds of derogation in Article 36, in fact the Court of Justice pursues the free movement of goods in the EU as a fundamental aim of Community law. So it increasingly becomes a worry for the Member States that national interests and policy, which are every important for the Member States and their citizens, are not within the scope of the EC law. However, the case of Gourmet showed that the approach of the Court of Justice in using the proportionality principle emphasizes the specific circumstances of each case. It means that the Court of Justice tries to extend the importance of the public interests that are sometimes ignored by Community law. Real consideration of the balance between the free movement of goods and public interests is therefore an interesting point in Gourmet. The proportionality principle is factually proportionate in Gourmet. So in the following parts, we will mainly concern ourselves with the questions: What is the definition of the proportionality principle? Why it is important for the Court of Justice in practice? How does the Court of Justice use the proportionality principle? Importantly, what are the different roles of the Court of Justice and the national courts in applying the proportionality principle?

\subsection{The concept of the proportionality principle}

The original legal root of the proportionality is Article 5 EC law. This indicates that action by the Community should not go beyond what is necessary to achieve the objectives of the treaty. This principle further requires the legality of Member State's action. However, from the case law of the Court of Justice, there is no precise definition of proportionality principle. But we can still see clearly that 'proportionality is not an independent principle of review, since it refers not to any particular free-standing substantive value, but rather to a relationship between other specific and possibly competing substantive interests.' (Note 22) In the other words, the proportionality is about the interests competing against each other. So it is necessary to focus precisely on the 
question of the reasonable relationship between an obvious objective and the other reasonable objectives. We can cite a German definition: 'the disputed measures be appropriate and necessary in order to attain the objective legitimately pursued by the legislation in question; that where there exists a choice between different means of achieving that objective recourses is to be had to the least dirigiste or interventionist of those measures; and, finally, it requires, more broadly, that the disadvantages caused must not be disproportionate to the aim pursued.' (Note 23) In short, the principle of proportionality means that the measures must be proportionate to its original objective.

It is worth noting that the principle of proportionality is in use in nearly whole of the Community legal system. It applies in two contexts: review of Community measures and review of national measures. The former context deals with challenges to Community measures. In the other word it exams the legality of provisions in regulations or directives. (Note 24) However, in this paper, we just focus on the later context. That means assessing the compatibility of a national measure with Community law. In detailed expression, especially in the context of the Article 28, the Court of Justice uses this principle to make a line between the lawful and unlawful impediments to free movement. On the one hand, it is a positive obligation for all the Member States to ensure the free movement of goods within the EU scope. They must not only treat imported goods, person, and services on an equal level but also ensure no obstacle to free access to the common market. However, national laws may concern public interests including public policy, safety, and public health. So the restriction on trade may be permissible, if it is objectively justified and proportionate. So, the proportionality principle is the instrument to determine the legality of the national restrictions. Although the proportionality principle is not the same as the concept of reasonableness(Note 25), protecting recognized interests is the real purpose of proportionality.

\subsection{The importance of the proportionality principle}

The importance of the proportionality is that it protects different interests and keeps the balance between them. This includes the balance between public interests and private interests and as well as between Community and national interests. On the one hand, the proportionality principle effects the free movement of goods. To some extent, this principle is liable to affect the marketing possibilities for imported products and protect unfettered access to the whole of the common market. The Court of Justice applies the proportionality principle to examine whether a national obstacle to trade is justified and proportionate. So, the Member States must choose the least restrictive alternative available among the trade prohibitions. As it is stated in the famous case Stoke-on-Trent (Note 26), 'Appraising the proportionality of national rules which pursue a legitimate aim under Community law involves weighing the national interests in attaining that aim against the Community interest in ensuring the free movement of goods. In that regard, in order to verify that the restrictive effects on intra-Community trade of the rules at issue do not exceed what is necessary to achieve the aim in view, it must be considered whether those effects are direct, indirect or purely speculative and whether those effects do not impede the marketing of imported products more than the marketing of national products.' (Note 27)

On the other hand, when the market integration maintains its leading role of the EU law, we need the proportionality principle to gain more attention for the public interests. National and public interests, to some extent, are the marginal areas within the Community law. There is no harmonization measure that requires Community law to protect the public interest. Therefore, it is the obligation of the national law to decide the degree of protection they afford the public interest.

The use of the proportionality principle in Article 28 is more important. Some authors consider that Article 28 entails the elimination of protectionism. Yet, I believe this view to be a little narrow, at least today. 'The function of Article 28 is a tool for policing the borderline resulting from the desired for integration and for (national) regulation.' (Note 28) Although there is no doubt that Article 28 is the preliminary ruling mechanism concerning the integration of the market in EU, should we ignore the national and public interests? We can see that, on the one hand, in order to achieve the free movement of goods in EU, 'the Community's efforts to integrate national markets are basically attempts to limit the influence of national governments on production and consumption activities throughout the Community. The desire to limit the influence of national government stems from economic as well ass political concerns.' (Note 29) But what about the public interest?

We should underline that Article 28 should be a borderline between legitimate and illegitimate national regulation. 'The very justification for limiting the autonomy of the Member States beyond a discrimination standard lies with the function of the Article 28.' (Note 30) However, we cannot see that in the past there was any proper test to keep the balance between these. Before the proportionality principle appeared, the court just considered the simple rule of Article 28 (Note 31). Consequently, they would rule against any discrimination towards imported products. After the Cassis De Dijon, this principle seems wider. 'All trading rules enacted by 
Member States which are capable of hindering, directly or indirectly, actually or potentially, intra-Community trade are to be considered as measures having effect equivalent to quantitative restrictions' (Note 32) On this point, national restrictions and public interests may more or less impede the intra-Community trade. All the national restrictions, to some extent, fall within the scope of Article 28. Although we cannot deny that some of the national restrictions contain protectionist bias, most of them concern national welfare and public interests. (Note 33) 'National governments are allowed, and supposed, to influence people's activities, but only to a certain extent. There is thus a continuous need to identify and police the border between legitimate and illegitimate national regulation.' (Note 34) How does the Community law respect the national legal system? How does the Community pay more attention to the public interests? The powerful Court of Justice begins to invite the Member States to a dialogue when using the proportionality principle. At the same time, it faces a challenging examination concerning all the relative objectives. So 'the proportionality principle does say something about the degree of Community interference; where possible Member States' legal systems should be respected.' (Note 35) The proportionality principle is indeed the safeguard of the national and public interests. The principle of proportionality greatly increases the opportunity for judicial intervention in Member States' decision-making. It makes the Court of Justice keep a balance between free movement of goods and high protection of public interests.

The proportionality principle brings fresh air. It is a reasonable and legitimate national tool for protecting the public interests. 'A common market requires free trade, but dose not require regulatory uniformity. National rules that do not partition the market should remain unaffected.' (Note 36) So, the proportionality principle may be the optimal test to reflect the balance between the national and public interests and the internal market. It constitutes a perfect standard for judging the degree of protection.

\subsection{The standards of the proportionality principle}

In order to gain a correct understanding of how the principle of proportionality might actually operate in the EU law, it is necessary to identify and consider the criteria of measuring the proportionality principle. The judicial process of weighing up different interests is actually kind of flexible balancing process that the Community rule on the one hand and that of the Member State in derogating, on the other hand. 'Appraising the proportionality of national rules which pursue a legitimate aim under Community law involves weighing the national interest in attaining that aim against the Community interest in ensuring the free movement of goods.' (Note 37) Although it is very difficult to consider all the necessary circumstances, 'the factors which will affect the "nature of review' or the 'degree of control', or 'level of scrutiny' a court will apply will depend on the respective nature of these interests in the particular circumstances.' (Note 38) So what are the generally accepted elements of the proportionality principle? The Court of Justice sometimes distinguishes two important elements of the proportionality principle: suitability and necessary. An good illustration can be found in the case Fedesa: (Note 39) The principle of proportionality...requires that the propitiatory measures are appropriate and necessary in order to attain the objectives legitimately pursued by the legislation in question... (Note 40) Although it is not the only standards the Court of Justice used even though the Court of Justice does not always apply them, these two elements are an ideal method for judging the proportionality principle.

\subsubsection{Suitability}

Firstly, it refers to whether the national measures can achieve the intended objective in the way that is suitable. There must, as it were, be a causal relationship between the means and end. "Suitable' seems to imply a less strict causal relationship than indispensable, while at the same time being less flexible than merely "useful" (Note 41) So as we have discussed in the Gourmet case, the national measures are prohibition on advertising and the intended objective is the protection of human health: in view of the health risks involved in alcohol consumption, alcoholic beverages should be marketed with particular moderation... the objective of the Alkoholreklamlagen is to restrict the possibilities of marketing alcoholic beverages to consumers. So we can see a clear causal relationship between the measure and its objective. The Court of Justice also tries to use a suitability standard in their judgements: 'There is no evidence before the Court to suggest that the public health grounds on which the Swedish authorities rely have been diverted from their purpose...' (Note 42)

Again, in the case Franzen (Note 43), the Court of Justice applied the standard of suitability. This case is about the legality of a Swedish obstacle to the importation of alcoholic beverages from the other Member States. Obviously, the aim of Swedish government is to limit the consumption of alcoholic beverages, in particular those of high alcoholic strength. So, its objective is public health. However, do its measures meet the standard of suitability? "Although the protection of human health against the harmful effects of alcohol, on which the Swedish Government relies, is indisputably one of the grounds which may justify derogation from Article 30 of 
the Treaty...the Swedish Government has not established that the licensing system set up by the Law on Alcohol, in particular as regards the conditions relating to storage capacity and the high fees and charges which licence-holders are required to pay, was proportionate to the public health aim pursued...' (Note 44) Obviously, the Court of Justice did not think the standard of suitability was met in this case.

Usually, it is not very hard for the Court of Justice to find the causal relationship between measures and their objectives. So, this standard needs the national courts to provide enough information, otherwise, the Court of Justice will be unable to apply the suitability criterion in the proportionality principle.

\subsubsection{Necessary}

A second standard of the proportionality principle is necessary. This is called the 'no measure less restrictive' criterion. This instrument can ensure the least negative effects for market integration when weighting the actual competing interests. 'It must be established whether the measures are necessary to achieve that aim, namely, whether there are other less restrictive means capable of producing the same result (the least restrictive test).' (Note 45) Again in the Gourmet case, although the Court of Justice did not answer this question of 'necessity', it did not fail to consider this basic element. 'Article 30 and 36 of the Treaty do not preclude a prohibition on the advertising of alcoholic beverages such as that laid down in Article 2 of the Alkoholreklamlagen, unless it is apparent that, in the circumstances of law and of fact which characterise the situation in the Member State concerned, the protection of public health against the harmful effects of alcoholic can be ensured by measures having less effect on intra-Community trade.' (Note 46)

In the case Familiapress (Note 47), it concerns the question of whether the national prohibition on the sale of periodicals containing prize competitions is liable to Article 28 of the Community law. The Court of Justice applied the 'necessary' in the proportionality principle. Although the Court of Justice left the final answer to the national court, as in the case of Gourmet, the Court of Justice pointed out: 'the provisions of national law in question must be proportionate to the objective pursued and that objective must not be capable of being achieved by measures which are less restrictive of intra-community trade.' (Note 48) In order to examine whether the Austrian legislature could have adopted less restrictive measures on the free movement of goods rather than an outright prohibition, the Court of Justice listed many situations that should be considered by the national court. This means it is necessary to find out the least restrictive alternative in the proportionality principle. 'Where a Member State has a choice between various measures to attain the same objective it is under an obligation to choose the means which least restrict the free movement of goods.' (Note 49)

It is worth noting that the standard of the least restrictive alternative does not mean the lowest level restriction. In the other words, the degree of restriction is not the standard; we cannot say any restriction is over restrictive just because we can find the less restrictive measures in the other Member States (Note 50). It is obviously not a race to the bottom. The point is whether we can find less restrictive measures but can achieve the same aim in this country.

All in all, although we discuss two standards of the proportionality principle, it is not a formalistic and mechanical test. The principle is by its nature flexible and depends on many factors. Not only legal issues but also social, administrative and economic issues are involved in this principle. So the degree of scrutiny remains is far from simple and easy.

\section{Conclusion}

'The successful construction and maintenance of the internal market depends heavily on leadership through accurate decision-making in the European Court of Justice.' (Note 51) In the other words, the creation of the European single market depends on the judgements of the Court of Justice. The judgement of the case Gourmet offers us an important lesson about the common market. First of all, the Court reversed the selling arrangement in Keck and stated market access approach, which means that the Court of Justice is using a more realistic approach by contrast with the formalism that it pursued in the past.

More importantly, the interpretation of the Gourmet has been understood as a development of the proportionality principle. 'An analysis of the circumstances of law and of fact which characterise the situation in the Member State concerned, which the national court is in a better position than the Court of Justice to carry out.' (Note 52) This approach is extremely interesting, given that the Court of Justice began to forego its role of controlling the European common market. It did not give a clear-cut way for deciding whether the national prohibition is proportionate. Instead, it carefully considered the national situation in details. So, the conclusion is that it is for the national court to decide whether the total ban is effective and justified. The judgement signals that the Court of Justice gave the public interest a great opportunity to survive. It should not be ignored by the European Union. 
Creating the single market without any obstacles is indeed the most important aim of the European Union, but it will be disappointing if the common market is not grounded on the principle of offering a high level protection to public and national interests. In fact, it is really dangerous for the EU if it loss some basic interests, including public interests.

So, as we said, we have focussed on the common market and the proportionality principle, which are the most important lessons we can learn from the case Gourmet. Firstly, we discussed the essentials of Gourmet to provide a basic understanding of the case. It shows clearly the Court of Justice transforms the selling arrangement into a market access approach and how the Court of Justice uses and analyses the proportionality principle in this case. Next, we focussed on access to the common market. We stated the history and detailed background of the common market, suggesting that the creation of the common market is indeed the most fundamental and important aim of the EU. Therefore, the Court of Justice has used certain formulae, including the Dassonville, Cassis and keck to make the concept of common market clear. These analyses show why the Gourmet case is a more perfect and suitable standard for Article 28. The market access approach meets the nature of the common market more fully and effectively.

Also, we considered a deep requirement of the common market: proportionality principle. We explored the nature and concept of the proportionality principle, then discussed the standards of this principle. A refined application of this principle in the case Gourmet shows that the Court of Justice and national courts interact to a considerable degree. In the other words, the Court of Justice cannot keep the balance between the Community law and national laws without the support of the national courts. More importantly, the proportionality principle promotes the development of the common market by safeguarding the public interests of member states.

'Since the mid-1980s, the Court has rendered on average 20 judgements a year relating to Article $30-36$. This accounts for approximately 8 per cent of all its judgements.' (Note 53) We can see clearly the importance of the common market, especially Article 28. In the Gourmet case, it is the first time that national rules imposing an almost total ban on advertising have not automatically fallen within the scope of the selling arrangement approach. The market access approach means the ending of formalism with regard to the category of the prohibition. At the same time, the Court of Justice began to extend the scope of its protection of public interests.

However, 'does it reflect sufficiently the interests and concerns put forward by the Member State when measures that breach Article 28 are being defended?' (Note 54) We can not deny that the market approach and the proportionality principle are flexible in the analysis of cases. They open a door for the Court of Justice to explain and perfect in future. The development of Community law now needs to be based on a broader concept of common market. What we expect is the development of a common market that is grounded on a determination to uphold public interests. It needs time to further develop and improve. Yet, we believe that the judgement of Gourmet is a ray of sunlight portending the gradual lifting of the fog and promises that a more flexible common market will be achieved in the near future. (Note 55)

\section{References}

(1994). Case Law. Common Market Law Review, 31.

(2002). Case C-405/98, Konsumentombusmannen (KO) v. Gourmet International Products AB (GIP), Judgment of the Court (Sixth Chamber) of 8 March 2001. Common Market Law Review, 39.

Anthony Arnull, Alan Dashwood, Malcolm Ross, Wyatt \& Dashwood. (2000). European Union Law. Sweet \& Maxwell.

Catherine Barnard \& Simon Deakin. (2002). Market Access and Regulatory Competition, the law of the single European Market unpacking the premises. Hart Publishing.

Damian Chalmers. (1994). Repackaging the Internal Market- The Ramifications of the Keck Judgment. European Law Review, 19.

Francis G. Jacobs. (1999). Recent Developments in the Principle of Proportionality in European Community Law. The Principle of Proportionality in Laws of Europe, Oxford.

Josephine Steiner \& Lorna Woods. (2003). Textbook on EC law. Oxford University Press.

Paul craig \& Grainne De Burca. (2002). EU Law: Text, Cases, and Materials. Oxford University Press.

Peter Oliver \& wulf-henning Roth. (2004). The Internal Market and four Freedoms. Common Market Law Review, 41. 
Rosa Greaves. (1998). Advertising Restrictions and the Free Movement of Goods and Services. European Law Review, 23.

Stephen Weatherill. (1996). After Keck: some thoughts on how to clarify the clarification. Common Market Law Review, 33.

Stephen Weatherill. (2003). Cases \& Materials on EU Law. Oxford University Press.

Takis Tridimas. (1999). The Principle of Proportionality: Review of National Measures, The General Principle of EC Law. Oxford University Press.

Weatherill, Stephen. (1999). EU Law. Penguin.

\section{Notes}

Note 1. Article 14 (2) of the EC Treaty

Note 2. Case C-405/98 Konsumentombudsmannen (KO) v. Gourmet International Products AB [2001] ECR I-1795

Note 3. Para 28 of the Gourmet judgment

Note 4. Para 4 of the Gourmet judgment

Note 5. The specialist press is the press addressed to manufacturers and restaurants, and bars which hold licence to serve alcohol.

Note 6. Para 15 of the opinion of Mr Advocate of General Jacobs

Note 7. Para 15 of the Keck judgment

Note 8. Para 18 of the Gourmet judgment

Note 9. Para 21 of Gourmet judgment

Note 10. Para 38 of the opinion of Mr Advocate of General Jacobs

Note 11. Para 25 of Gourmet judgment

Note 12 . Article 30 of the treaty

Note 13. Para $4 \&$ para 5 of Gourmet judgment

Note 14. Para 42 of the opinion of Mr Advocate of General Jacobs

Note 15. Para 32 of Gourmet judgment

Note 16. Para 28 of Gourmet judgment

Note 17. Para 29 of Gourmet judgment

Note 18. Para 30 of the Gourmet judgment

Note 19. Para 31 of the Gourmet judgment

Note 20. Para 64 of the opinion of Mr Advocate of General Jacobs

Note 21. Para 34 of the Gourmet judgment

Note 22. Grainne de Burca, the principle of proportionality and its application in EC law, Yearbook of European law, Oxford, 13, 1994, 106

Note 23. Nicholas Green, Proportionality and the Supremacy of Parliament in the UK, The principle of Proportionality in the laws of Europe, Oxford, 1999, 146

Note 24. Walter Van Gerven, The effect of Proportionality on the Actions of Member States of the European Community: National Viewpoints from Continental Europe, The principle of Proportionality in the laws of Europe, Oxford, 1999, 39

Note 25. 'In a case before the European Court of Justice in 1979, Advocate General Warner suggested that the proportionality principle was essentially the same as the concept of reasonableness.' (Grainne de Burca, the principle of proportionality and its application in EC law, Yearbook of European law, Oxford, 13, 1994, 108)

Note 26. Case C-169/91 Council of the City of Stoke-on-Trent and Another v. B \& Q [1992] ECR I-6635

Note 27. Para 15 of the Stoke-on-Trent judgment

Note 28. Wouter P. J. Wils, The search for the rule in Article 30 EEC: much ado about nothing, European Law Review, 18, 1993, 491 
Note 29. Ibid., 476

Note 30. Case law, Common Market Law Review, 31,1994,853

Note 31. 'Article 28 forbids national rules that discriminate against imported products, subject to the possibility that the member state may find justification for its practices under Article 30. However, the scope of Article 28 extends beyond the discriminatory national rule. Even if a national rule on its face makes no distinction between domestic and imported products.' (Weatherill ,Stephen ,EU Law, Penguin, 1999, 565)

Note 32. Para 5 of the judgment

Note 33. 'National measures restrict people in their economic activities throughout the Community, often at the expense of common welfare.' (Wouter P. J. Wils, The search for the rule in Article 30 EEC: much ado about nothing, European Law Review, 18, 1993, 476)

Note 34. Ibid., 477

Note 35. Jan H. Jans, Proportionality Revisited, Legal issues of European Integration 27 (3), 2000, 243

Note 36. Weatherill ,Stephen ,EU Law, Penguin, 1999, 608

Note 37. It is the proportionality principle described in the case C-169/91 Council of the City of Stoke-on-Trent and Norwich City Council v. B \& Q Plc [1992] ECR I-6635.

Note 38. Grainne de Burca, the principle of proportionality and its application in EC law, Yearbook of European law, Oxford, 13, 1994, 114

Note 39. Case C-331/88 [1990] ECR 4023

Note 40. Walter Van Gerven, The effect of Proportionality on the Actions of Member States of the European Community: National Viewpoints from Continental Europe, The principle of Proportionality in the laws of Europe, Oxford, 1999, 38

Note 41. 'This criterion gives the Court of Justice a means of acting against national measures which are essentially protectionist but are presented as being necessary to protect a legitimate interest.' ( Jan H. Jans, Proportionality Revisited, Legal issues of European Integration 27 (3), 2000, 243)

Note 42. Para 32 of Gourmet judgment

Note 43. Case C-189/95 Franzen [1997] ECR I-5909

Note 44. Para 76 of the Franzen judgment

Note 45. Takis Tridimas, Proportionality in Community law: searching for the appropriate standard of scrutiny, The principle of Proportionality in the laws of Europe, Oxford, 1999, 68

Note 46. Para 34 of the Gourmet judgment

Note 47. Case [1997] E.C.R. I-3689

Note 48. Para 19 of the Familiapress judgment

Note 49. Takis Tridimas, The general principles of EC law, Oxford University Press, 1999.

Note 50. 'Alpine Investments shows that whether a restriction on marketing technique passes the test of proportionality should be assessed inter alia by reference to the conditions prevailing in the national market and the reasons which led to its adoption. Although in that case there was clearly a less restrictive alternative operative in another Member State, the Court focused on the effects of the restriction rather than on a comparison between the laws of different Member States.' (Takis Tridimas, The general principles of EC law, Oxford University Press, 1999, 139)

Note 51. Stephen Weatherill, After Keck: Some Thoughts on How to Clarify the Clarification, Common Market Law Review, 33, 1996

Note 52. Para 33 of Gourmet judgment

Note 53. Wouter P.J. Wils, The Search for the rule in Article 30 EEC: much ado about nothing?, European Law Review 18, 1993

Note 54. Ibid.

Note 55. As Alina Kaczorowska states in the article Gourmet Can Have His Keck and Eat It!: 'In the author's submission, the Court of Justice decision in Gourmet is a ray of sunlight portending the gradual lifting of the fog in that the Court of Justice has in this case initiated a new, more realistic approach to national 